\title{
Predicting near-term variability in ocean carbon uptake
}

\author{
Nicole S. Lovenduski ${ }^{1}$, Stephen G. Yeager ${ }^{2}$, Keith Lindsay ${ }^{2}$, and Matthew C. Long ${ }^{2}$ \\ ${ }^{1}$ Department of Atmospheric and Oceanic Sciences and Institute of Arctic \\ and Alpine Research, University of Colorado, Boulder, Colorado, USA \\ ${ }^{2}$ Climate and Global Dynamics Laboratory, National Center \\ for Atmospheric Research, Boulder, Colorado, USA
}

Correspondence: Nicole S. Lovenduski (nicole.lovenduski@ colorado.edu)

Received: 27 September 2018 - Discussion started: 5 October 2018

Revised: 23 December 2018 - Accepted: 14 January 2019 - Published: 24 January 2019

\begin{abstract}
Interannual variations in air-sea fluxes of carbon dioxide $\left(\mathrm{CO}_{2}\right)$ impact the global carbon cycle and climate system, and previous studies suggest that these variations may be predictable in the near term (from a year to a decade in advance). Here, we quantify and understand the sources of near-term predictability and predictive skill in air-sea $\mathrm{CO}_{2}$ flux on global and regional scales by analyzing output from a novel set of retrospective decadal forecasts of an Earth system model. These forecasts exhibit the potential to predict year-to-year variations in the globally integrated air-sea $\mathrm{CO}_{2}$ flux several years in advance, as indicated by the high correlation of the forecasts with a model reconstruction of past $\mathrm{CO}_{2}$ flux evolution. This potential predictability exceeds that obtained solely from foreknowledge of variations in external forcing or a simple persistence forecast, with the longest-lasting forecast enhancement in the subantarctic Southern Ocean and the northern North Atlantic. Potential predictability in $\mathrm{CO}_{2}$ flux variations is largely driven by predictability in the surface ocean partial pressure of $\mathrm{CO}_{2}$, which itself is a function of predictability in surface ocean dissolved inorganic carbon and alkalinity. The potential predictability, however, is not realized as predictive skill, as indicated by the moderate to low correlation of the forecasts with an observationally based $\mathrm{CO}_{2}$ flux product. Nevertheless, our results suggest that year-to-year variations in ocean carbon uptake have the potential to be predicted well in advance and establish a precedent for forecasting air-sea $\mathrm{CO}_{2}$ flux in the near future.
\end{abstract}

\section{Introduction}

Observations collected over the past few decades indicate that the ocean has absorbed $160 \mathrm{Pg}$ of excess carbon from the atmosphere since the beginning of the industrial revolution (Le Quéré et al., 2018); projections from climate models suggest that $\sim 540 \mathrm{Pg}$ of excess carbon will reside in the ocean by the end of the century (under the RCP8.5 emission scenario; Ciais and Sabine, 2013). Accurate projections of past and future air-sea $\mathrm{CO}_{2}$ flux are important for quantifying and understanding the changing global carbon cycle and for estimating future global climate change (Le Quéré et al., 2018).

Superimposed on the background of long-term changes in ocean carbon uptake is substantial variability on global and regional scales (McKinley et al., 2017; Landschützer et al., 2016). The recent literature highlights ocean carbon uptake variability that manifests on timescales of years to decades. Interannual variability in globally integrated air-sea $\mathrm{CO}_{2}$ flux has been estimated to have a standard deviation of 0.31 and $0.2 \mathrm{Pg} \mathrm{Cyr}^{-1}$ from observationally based products (Rödenbeck et al., 2015) and ocean biogeochemical models (Wanninkhof et al., 2013), respectively, which is of the order of $10 \%$ of the global mean $\mathrm{CO}_{2}$ flux $\left(2.3 \mathrm{Pg} \mathrm{C} \mathrm{yr}^{-1}\right)$. A global extrapolation of sparse $p \mathrm{CO}_{2}$ observations suggests that there is large variability on decadal timescales (Landschützer et al., 2016). On regional scales, Southern Ocean studies have highlighted recent air-sea $\mathrm{CO}_{2}$ flux variability on interannual (Wetzel et al., 2005; Lenton and Matear, 2007; Lovenduski et al., 2007, 2013, 2015a; Verdy et al., 
2007; Wang and Moore, 2012; Hauck et al., 2013; Lenton et al., 2013) and decadal (Fay et al., 2014; Landschützer et al., 2015; Munro et al., 2015) timescales. In the North Atlantic, high air-sea $\mathrm{CO}_{2}$ flux variability has been linked to the North Atlantic Oscillation (Thomas et al., 2008; Ullman et al., 2009) and the Atlantic Multidecadal Oscillation (Metzl et al., 2010; Breeden and McKinley, 2016), whose spectra peak at interannual and multi-decadal timescales.

Near-term predictions of the climate system (so-called "decadal predictions") are forecasts of climate variability and change on annual, multi-annual, and decadal timescales from global climate models (Meehl et al., 2014). These forecasts are sensitive to both initial conditions (e.g., the atmospheric temperature used to initialize the forecasts) and external forcing (e.g., the long-term increase in atmospheric temperature associated with increasing greenhouse gas concentrations; Kirtman et al., 2013). Recent publications highlight nearterm predictability and predictive skill in regional surface air temperature, precipitation, Arctic sea ice concentration, oceanic heat content, and the large-scale Atlantic Ocean circulation (Smith et al., 2007; Keenlyside et al., 2008; Meehl et al., 2009, 2014; Robson et al., 2012; Yeager et al., 2012, 2015; Yeager and Robson, 2017; Boer et al., 2016). As prior literature has established a strong link between air-sea $\mathrm{CO}_{2}$ flux and variability in the physical climate system on these timescales (e.g., Resplandy et al., 2015; McKinley et al., 2017), it follows that air-sea $\mathrm{CO}_{2}$ flux may be predictable in the near term.

Here, we analyze a novel set of decadal prediction simulations from an Earth system model (ESM) to investigate near-term predictions of global and regional ocean carbon uptake. On annual to decadal timescales, ESM predictions of the past (so-called "retrospective forecasts") are used to assess both predictability and predictive skill in air-sea $\mathrm{CO}_{2}$ flux. Predictability is the potential to predict the system based on forecast verification against a model reconstruction. Predictive skill is based on forecast verification against observations. We further assess the role of external forcing in the predictability of $\mathrm{CO}_{2}$ flux by analyzing a set of uninitialized forecasts run under identical external forcing. By analyzing forecasts of the past, our study establishes a precedent for making skillful predictions of ocean carbon uptake in the near future.

\section{Community Earth System Model Decadal Prediction System}

Our primary numerical tool is the Community Earth System Model Decadal Prediction Large Ensemble (CESM-DPLE; Yeager et al., 2018). In this section, we describe the model and provide details about forecast initialization, ensemble generation, and drift correction. Importantly, we note that this is the first CESM decadal prediction system to include a representation of ocean biogeochemistry. CESM-DPLE uses the same code base as the CESM Large Ensemble (CESMLE; Kay et al., 2015).

The CESM is a state-of-the-art coupled climate model consisting of atmosphere, ocean, land, and sea ice component models (Hurrell et al., 2013; Danabasoglu et al., 2012; Lawrence et al., 2012; Hunke and Lipscomb, 2008). The ocean physical model (version 2 of the Parallel Ocean Program; Danabasoglu et al., 2012) has nominal $1^{\circ}$ horizontal resolution and 60 vertical levels. The biogeochemical ocean model represents the lower trophic levels of the marine ecosystem (Moore et al., 2004, 2013), full carbonate system thermodynamics (Long et al., 2013), air-sea $\mathrm{CO}_{2}$ fluxes, and a dynamic iron cycle (Doney et al., 2006; Moore and Braucher, 2008).

CESM-DPLE consists of a set of initialized, fully coupled integrations of CESM that adhere to the protocols for Component A of the Decadal Climate Prediction Project (Boer et al., 2016). We use the CESM-DPLE system (Yeager et al., 2018) that builds on previous CESM decadal prediction efforts (Yeager et al., 2012, 2015) with some modifications (including the addition of ocean biogeochemistry, as noted above). CESM-DPLE initiates 40 decade-long "forecasts" of the Earth system each year from 1954-2015; the start date for each forecast is 1 November, in accordance with the DCPP protocols. Each of the model integrations is subject to a common set of historical external forcings (e.g., greenhouse gas concentrations).

The ocean physical and biogeochemical initial conditions for the DP experiments are generated from a forced oceansea ice simulation of the CESM. That is, a simulation of the ocean and ice components of the CESM that has been forced with fluxes computed from the observed atmospheric state over 1948-2015. This simulation is therefore meant to reconstruct the historical evolution of the ocean physical and biogeochemical state over the 1948-2015 period (Fig. 1). Hereafter, we refer to this simulation as the "reconstruction". Initial conditions from the atmosphere and land components of the DP experiments are obtained from a 20th century simulation of the CESM Large Ensemble (Kay et al., 2015).

Ocean biogeochemistry in the version of the CESM used for CESM-DPLE has been extensively validated in the literature (Long et al., 2016; Lovenduski et al., 2016; McKinley et al., 2016; Krumhardt et al., 2017; Freeman et al., 2018). In particular, the simulated mean, variability, and trends in surface ocean $p \mathrm{CO}_{2}$ and air-sea $\mathrm{CO}_{2}$ flux from CESM over 1982-2011 compare favorably to estimates from observations for the global average and over most ocean biogeochemical biomes (McKinley et al., 2016; Lovenduski et al., 2016). In Fig. 2, we illustrate the comparison between observationally based estimates of $\mathrm{CO}_{2}$ flux (from the Landschützer et al., 2016, $p \mathrm{CO}_{2}$ product) and estimates produced by the reconstruction and coupled CESM-LE over 19822015. The model reconstruction does a reasonable job $(r=$ 0.79 ) of representing observed spatial patterns (in both magnitude and direction) of the flux across most oceanic re- 


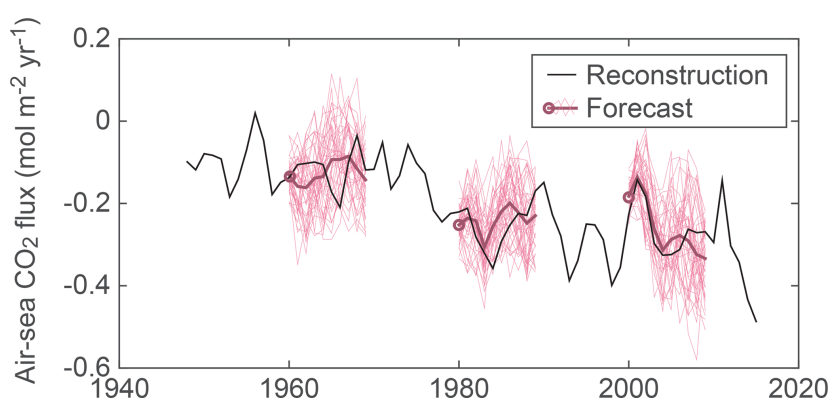

Figure 1. Annual mean air-sea $\mathrm{CO}_{2}$ flux $\left(\mathrm{mol} \mathrm{m}^{-2} \mathrm{yr}^{-1}\right)$ in the South Pacific subtropical permanently stratified biome for the (black) model reconstruction and (pink) CESM-DPLE decadal forecasts initiated in 1960, 1980, and 2000 (other forecasts omitted for visual clarity). The thick magenta line represents the ensemble mean forecast; open circles show the ensemble mean in forecast year 1. Positive fluxes denote ocean outgassing. Forecasts have been drift-corrected and adjusted to match the reconstruction climatological mean for ease of visual comparison.

gions. The globally integrated air-sea $\mathrm{CO}_{2}$ fluxes over 1982 2015 from the observational product and model reconstruction are 1.41 and $1.80 \mathrm{Pg} \mathrm{C} \mathrm{yr}^{-1}$, respectively (directed into the ocean).

CESM-DPLE initializes an ensemble of 40 simulations each year using round-off-level (order $10^{-14}$ ) perturbations in the initial air temperature field (Fig. 1). Previous work indicates that this small perturbation in the initial conditions generates a wide divergence in global mean surface temperatures across the ensemble members within about 30 days (Vineel Yettella, personal communication, 2018), and the average divergence in globally integrated, annual mean forecast $\mathrm{CO}_{2}$ flux across the ensemble members $\left(0.53 \mathrm{Pg} \mathrm{C} \mathrm{yr}^{-1}\right)$ is an order of magnitude greater than that generated by the preindustrial control simulation of CESM $\left(0.09 \mathrm{Pg} \mathrm{Cyr}^{-1}\right.$; Lovenduski et al., 2015b). Each ensemble member is subject to identical external forcing. The number of ensemble members in each forecast ensures statistically robust drift estimates (see below; Boer et al., 2013; Kirtman et al., 2013; Yeager et al., 2018).

Following initialization, the coupled model drifts toward its preferred state over the decadal forecast. This is a common problem for full-field initialization decadal prediction experiments (Meehl et al., 2014) and requires a drift correction to be applied to the model forecasts before predictability and predictive skill may be analyzed. We correct the drift by transforming to anomalies from a drifting climatology, as in Yeager et al. $(2012,2018)$. For a given forecast, $X(L, M, S)$, where $L$ is the forecast length, $M$ is the ensemble member, and $S$ is the start year of the forecast; the drift-corrected forecast anomaly, $X^{\prime}(L, M, S)$, is defined as

$X^{\prime}(L, M, S)=X(L, M, S)-\overline{X(L, M, S)}^{M, S}$, where $\overline{X(L, M, S)}^{M, S}$ is the average rate of drift over all forecasts. Note that this method does not assume that the drift is linear and disregards potential dependence of the drift on the external forcing.

Predictive skill in CESM-DPLE may be enabled by external forcing (e.g., the time evolution of atmospheric greenhouse gases) as well as by initialization. To assess the role of initialization in predictability, we compare CESM-DPLE air-sea $\mathrm{CO}_{2}$ flux (generated with the initialization procedure described above) with air-sea $\mathrm{CO}_{2}$ flux from the CESMLE (McKinley et al., 2016; Lovenduski et al., 2016) over the same historical period. The CESM-LE is a 32-member ensemble of the CESM with fully resolved ocean biogeochemistry that evolves the Earth system from 1920 to 2100 under historical and RCP8.5 forcing (Kay et al., 2015). As such, CESM-LE represents the uninitialized counterpart to the CESM-DPLE system; output from CESM-LE can tell us how the modeled air-sea $\mathrm{CO}_{2}$ flux would evolve over a given decade in the absence of initialization, but under the same external forcing.

\section{Results}

\subsection{Predictability}

Predictability is a property of a system that characterizes the potential for its future evolution to be predicted; this concept is distinct from that of model skill. We quantify predictability by evaluating the ability of the CESM-DPLE initialized forecasts to predict variations in air-sea $\mathrm{CO}_{2}$ flux from the reconstruction. For a given forecast anomaly, $X^{\prime}(L, M, S)$, predictability is defined as the correlation coefficient of $X^{\prime}(L$, $M, S$ ) with the corresponding anomaly in the reconstruction; the reconstruction anomaly is obtained by subtracting the climatological mean value over 1955-2015.

The globally integrated air-sea $\mathrm{CO}_{2}$ flux anomaly from the initialized CESM-DPLE in forecast year 1 exhibits high correlation with the $\mathrm{CO}_{2}$ flux anomaly from the reconstruction (Fig. 3a; $r=0.98$ ). This correlation remains high and statistically significant (at the $95 \%$ level using a two-sided Student's $t$ test while accounting for autocorrelation in the sample size) for 10 forecast lead years (Fig. 3c), suggesting high, long-lasting predictability in the globally integrated air-sea $\mathrm{CO}_{2}$ flux.

We further investigate whether the predictability in the globally integrated air-sea $\mathrm{CO}_{2}$ flux is a function of initialization by (1) correlating integrated $\mathrm{CO}_{2}$ flux anomalies from the ensemble mean of the uninitialized CESM-LE simulation with anomalies from the reconstruction and (2) generating a persistence forecast (autocorrelation as a function of lead time) for the $\mathrm{CO}_{2}$ flux anomalies from the reconstruction. Figure $3 \mathrm{a}$ and $\mathrm{c}$ reveal that the initialization of the forecast does not much improve the prediction from the uninitialized forecast. This is because the strong externally forced component of the forecast (e.g., the rising $\mathrm{CO}_{2}$ concentration in the 
(a) Observationally based product

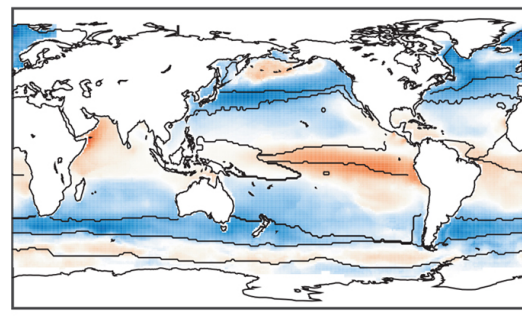

(b) Reconstruction

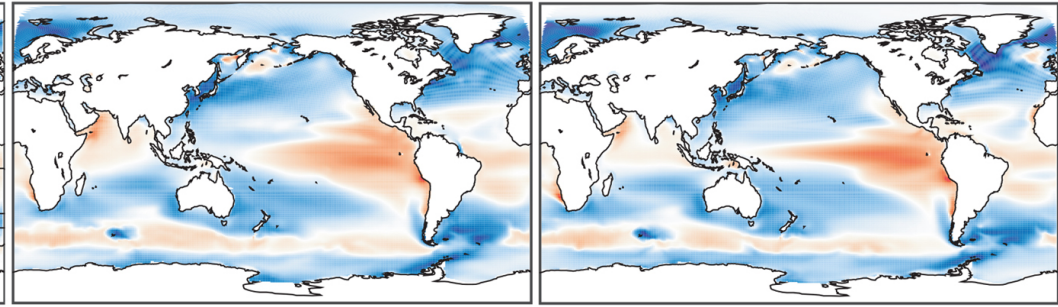

$-5$

0

5

Figure 2. Annual mean air-sea $\mathrm{CO}_{2}$ flux $\left(\mathrm{mol} \mathrm{m}^{-2} \mathrm{yr}^{-1}\right.$ ) over the period 1982-2015 as estimated by (a) the Landschützer et al. (2016) observationally based product, (b) the model reconstruction, and (c) the CESM-LE. Positive fluxes denote ocean outgassing, and black contours in (a) show biome boundaries.
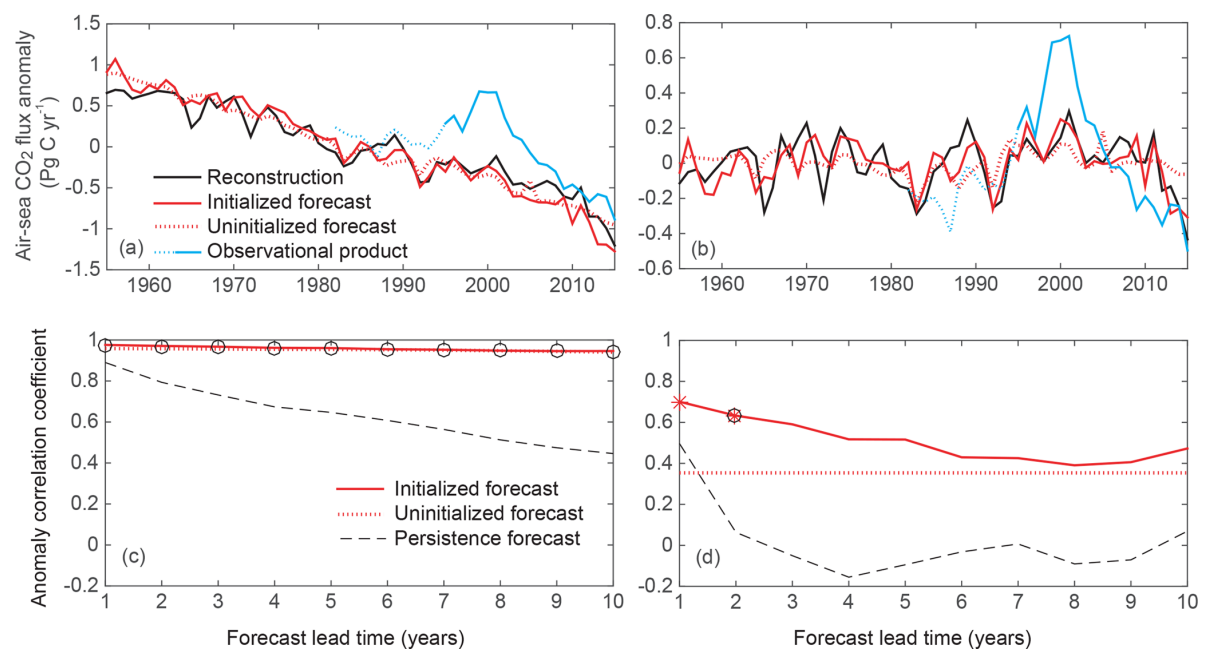

Figure 3. (a) Temporal evolution of the globally integrated air-sea $\mathrm{CO}_{2}$ flux anomaly, as estimated by the (black) reconstruction, (red) CESM-DPLE initialized forecast, (red dotted) CESM-LE uninitialized forecast, and (blue) Landschützer et al. (2016) observationally based product. The CESM-DPLE time series is the drift-corrected, ensemble mean forecast anomalies over lead year 1; the reconstruction, uninitialized forecast, and observational product have been transformed to anomalies by subtracting their respective climatological means. Observations prior to 1995 are dotted due to lower observation density. Positive anomalies indicate anomalous ocean outgassing. (b) Same as (a), but with long-term linear trends removed from each time series. (c) Predictability of globally integrated $\mathrm{CO}_{2}$ flux as a function of lead time, as indicated by the correlation coefficient of $\mathrm{CO}_{2}$ flux anomalies from the (red) CESM-DPLE initialized forecast, and the (red dotted) CESM-LE uninitialized forecast with the reconstruction. The black dashed line indicates the correlation coefficient of the persistence forecast as a function of lead time. Red asterisks (black circles) on the initialized forecast indicate predictability that is statistically different from the uninitialized (persistence) forecast at the $95 \%$ level using a $z$ test. (d) Same as (c), but with linear trends removed from each time series.

atmosphere) provides an important source of predictability in both the initialized and uninitialized forecasts. While the persistence forecast also yields high correlation coefficients, both the initialized and uninitialized forecasts beat persistence for all prediction lead times (Fig. 3c).

Figure $3 \mathrm{a}$ also reveals interannual variability in the globally integrated air-sea $\mathrm{CO}_{2}$ flux. While this variability is swamped by the externally forced signal (i.e., the increasing $\mathrm{CO}_{2}$ uptake due to rising atmospheric $\mathrm{CO}_{2}$ ), we are nevertheless interested in the ability of CESM-DPLE to forecast this year-to-year variability. To accomplish this, we remove the linear trend from the forecasts and the reconstruction before computing predictability; this method produces estimates of correlation that are not dominated by the trend induced by external forcing. The globally integrated, detrended air-sea $\mathrm{CO}_{2}$ flux anomaly from the initialized CESM-DPLE in lead year 1 exhibits high correlation with $\mathrm{CO}_{2}$ flux from the reconstruction (Fig. 3b; $r=0.70$ ), suggesting high predictability of ocean carbon uptake variability on interannual timescales as well. While this predictability drops off with forecast lead time, we nevertheless find high correlations $(r>0.5)$ between the annual mean $\mathrm{CO}_{2}$ flux forecast anomalies and detrended reconstruction anomalies that extend for 4 years (Fig. 3d). 


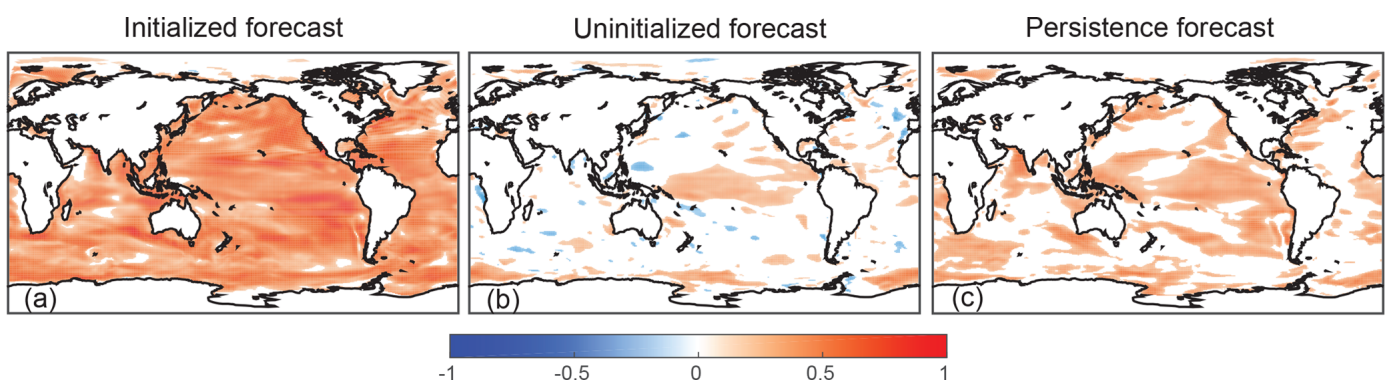

Figure 4. Predictability of air-sea $\mathrm{CO}_{2}$ flux, as indicated by the correlation coefficient of detrended air-sea $\mathrm{CO}_{2}$ flux anomalies from the (a) CESM-DPLE initialized forecast lead year 1 with the reconstruction and the (b) CESM-LE uninitialized forecast with the reconstruction. (c) Correlation coefficient of the persistence forecast for lead year 1. Correlation coefficients that are not statistically significant at the $95 \%$ level using a $t$ test are assigned a value of zero.

Interannual variability in global air-sea $\mathrm{CO}_{2}$ flux may also be affected by interannual variability in external forcing (e.g., volcanoes). As above, we evaluate the role of initialization by calculating uninitialized predictability and estimating persistence. Figure 3 indicates that the initialized forecast exhibits higher predictability than the uninitialized forecast and the persistence forecast for a lead time of 10 years, though this initialized predictability is only statistically separable from the uninitialized and persistence forecasts for lead years 12 and 2, respectively; statistical separation was determined via a Fisher's $r$ to $z$ transformation and a comparison of the resulting $z$ test statistic to the value for the $95 \%$ confidence interval (1.96). Thus, the CESM-DPLE initialized forecasts have the potential to predict year-to-year variations of globally integrated air-sea $\mathrm{CO}_{2}$ flux several years in advance.

The results from our analysis of the globally integrated air-sea $\mathrm{CO}_{2}$ flux suggest that interannual variations in global ocean carbon uptake may be predictable in advance. They further indicate that initialization of the forecasts enhances the predictability of future interannual variations over and above the predictability from variations in the external forcing, such as those imposed by volcanic eruptions. This is a particularly meaningful result for those forecasting yearto-year changes in the global carbon budget (e.g., Le Quéré et al., 2018), especially as these forecasting efforts are blind to the externally forced variability in advance (i.e., the external forcing of the future is unknown). In this way, nearterm predictions of air-sea $\mathrm{CO}_{2}$ flux variations can help to inform future predictions of land-air $\mathrm{CO}_{2}$ flux and atmospheric $\mathrm{CO}_{2}$.

Given the high predictability and the important role of initialization in forecasts of interannual air-sea $\mathrm{CO}_{2}$ fluxes on a global scale, we next investigate the spatial patterns of airsea $\mathrm{CO}_{2}$ flux predictability across the global ocean. Here, we use the same statistical techniques as for the global flux, but instead perform an analysis in each model grid cell. On a global scale, the evolution of air-sea $\mathrm{CO}_{2}$ flux is dominated by the long-term increase in ocean uptake (see, e.g., Fig. 3a), whereas on local and regional scales, the evolution is dominated by interannual variability (Fig. 1; see also, e.g., Lovenduski et al., 2016). To capture the predictability on interannual timescales, we perform an analysis on linearly detrended forecasts in each model grid cell. Figure 4a illustrates the large predictability of initialized $\mathrm{CO}_{2}$ flux across much of the global ocean for forecast lead year 1 (additional forecast lead years shown in Fig. S1 in the Supplement). The uninitialized forecast (Fig. 4b) and the persistence forecast (Fig. 4c) indicate lower predictability.

If not external forcing or persistence, what drives the high predictability in air-sea $\mathrm{CO}_{2}$ flux interannual variability? We decompose the predictability of air-sea $\mathrm{CO}_{2}$ flux $(\Phi)$ over forecast lead year 1 by considering the predictability of its drivers:

$\Phi=k \cdot S_{0} \cdot(1-$ ice $) \cdot \Delta p \mathrm{CO}_{2}$,

where $k$ is the piston velocity (also known as the gas transfer coefficient), $S_{0}$ is the solubility of $\mathrm{CO}_{2}$ in seawater, "ice" is the fraction of the ocean covered by sea ice, and $\Delta p \mathrm{CO}_{2}$ is the difference between the oceanic $p \mathrm{CO}_{2}$ and the atmospheric $p \mathrm{CO}_{2}$. As for $\mathrm{CO}_{2}$ flux, predictability is defined as the anomaly correlation coefficient of each driver variable in forecast year 1 with the corresponding anomaly of that driver variable in the reconstruction, e.g., the correlation of anomalous piston velocities from the forecast with those from the reconstruction. Figure 5 shows the predictability of each of the $\mathrm{CO}_{2}$ flux driver variables; the anomaly correlation coefficients are scaled to $\mathrm{CO}_{2}$ flux units $\left(\mathrm{mol} \mathrm{m}^{-2} \mathrm{yr}^{-1}\right)$ and can be easily compared. The predictability scaling is achieved by multiplying the anomaly correlation coefficient $(r)$ by the sensitivity of $\mathrm{CO}_{2}$ flux to each driver variable $(x)$ and the standard deviation of the driver variable time series:

$r \cdot \frac{\partial \Phi}{\partial x} \cdot \sigma_{x}$

where the sensitivities and standard deviations are established from model-estimated, annual mean quantities in each grid cell (as in, e.g., Lovenduski et al., 2007, 2013, 2015a) using annual averages from the reconstruction. The $\mathrm{CO}_{2}$ flux 

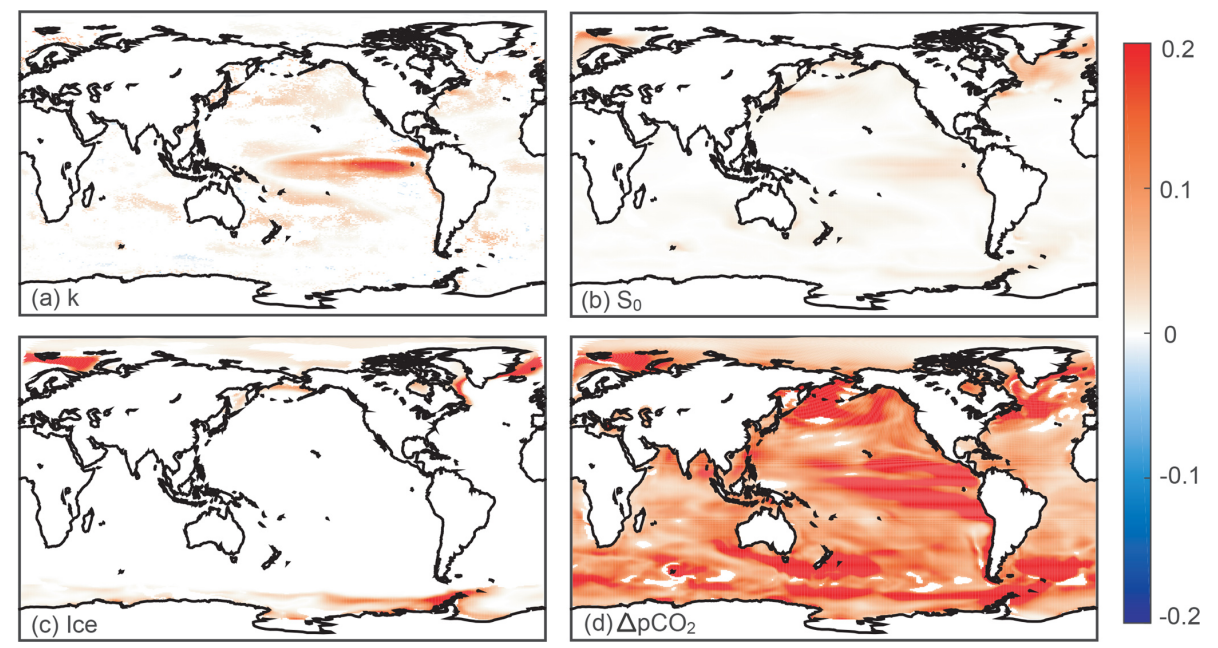

Figure 5. Drivers of predictability in air-sea $\mathrm{CO}_{2}$ flux during forecast year 1, as indicated by the predictability of the (a) gas exchange coefficient, (b) solubility, (c) sea ice fraction, and (d) $\Delta p \mathrm{CO}_{2}$, scaled to $\mathrm{CO}_{2}$ flux units $\left(\mathrm{mol} \mathrm{m}^{-2} \mathrm{yr}^{-1}\right)$. Correlation coefficients that are not statistically significant at the $95 \%$ level using a $t$ test are assigned a value of zero.
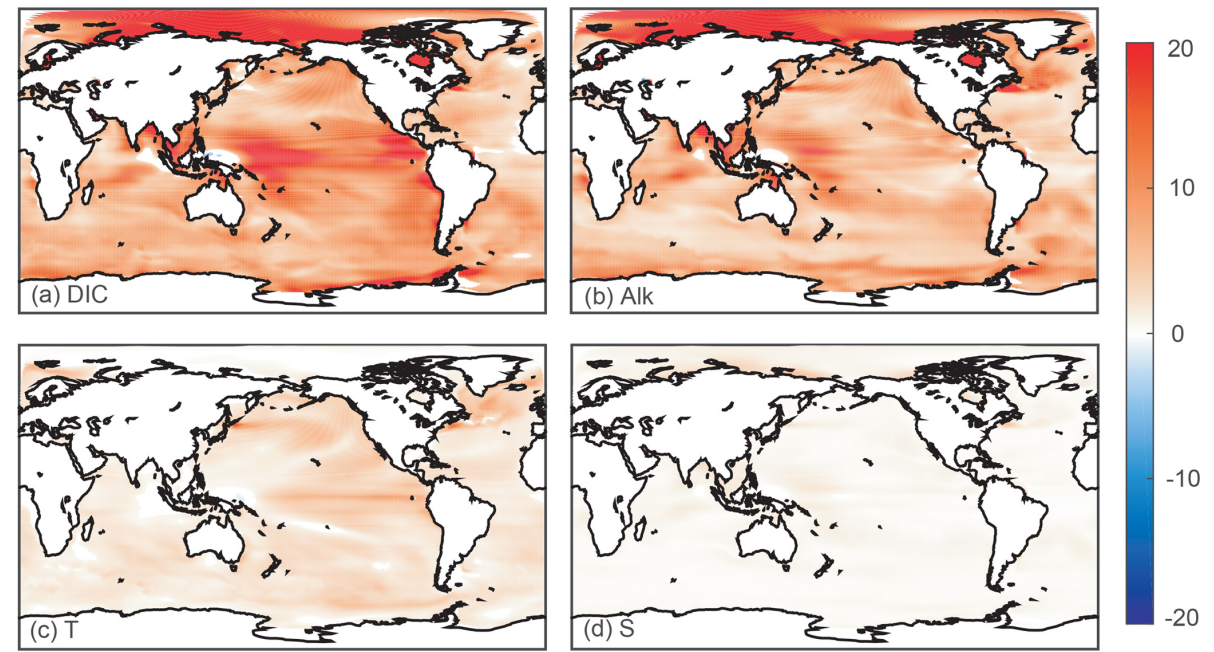

Figure 6. Drivers of predictability in surface ocean $p \mathrm{CO}_{2}$ during forecast year 1, as indicated by the predictability of surface ocean (a) DIC, (b) Alk, (c) temperature, and (d) salinity, scaled to $p \mathrm{CO}_{2}$ units ( $\mu \mathrm{atm}$ ). Correlation coefficients that are not statistically significant at the $95 \%$ level using a $t$ test are assigned a value of zero.

predictability is largely driven by predictability in $\Delta p \mathrm{CO}_{2}$ across the global ocean (Fig. 5). Our results suggest secondary roles for the piston velocity in the equatorial $\mathrm{Pa}$ cific, solubility in the North Atlantic subpolar gyre, and sea ice fraction in the Arctic-North Atlantic and high-latitude Southern Ocean. Elsewhere, these other driver variables play only minor roles in $\mathrm{CO}_{2}$ flux predictability.

As the large predictability in $\triangle p \mathrm{CO}_{2}$ is caused by the predictability of surface ocean $p \mathrm{CO}_{2}$ in our model framework (i.e., atmospheric $\mathrm{CO}_{2}$ concentration is prescribed rather than predicted), we next investigate the drivers of interannual predictability in surface ocean $p \mathrm{CO}_{2}$ : dissolved inorganic carbon (DIC), alkalinity (Alk), temperature $(T)$, and salinity $(S)$.
We use a similar approach as for $\mathrm{CO}_{2}$ flux, but here the sensitivities are derived from carbonate chemistry approximations (Lovenduski et al., 2007; Doney et al., 2009; Long et al., 2013), and all drivers are scaled to $p \mathrm{CO}_{2}$ units ( $\left.\mu \mathrm{atm}\right)$ for ease of comparison:

$r \cdot \frac{\partial p \mathrm{CO}_{2}}{\partial x} \cdot \sigma_{x}$.

The surface ocean $p \mathrm{CO}_{2}$, and thus the air-sea $\mathrm{CO}_{2}$ flux predictability, for forecast lead year 1 is largely driven by predictability in surface ocean DIC and Alk, with temperature playing a secondary role and salinity a minor role (Fig. 6). The similar predictability of DIC and Alk across many regions hints at an important role for ocean circulation, rather 


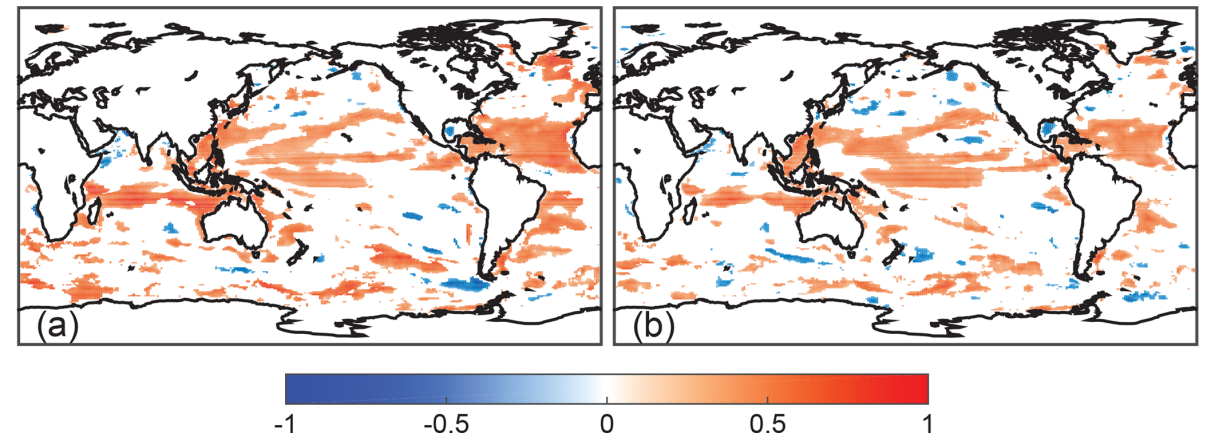

Figure 7. Air-sea $\mathrm{CO}_{2}$ flux predictive skill, as indicated by the correlation coefficient of air-sea $\mathrm{CO}_{2}$ flux (a) anomalies, and (b) linearly detrended anomalies from the CESM-DPLE initialized forecast in year 1 with the Landschützer et al. (2016) observational product over 19952015. Correlation coefficients that are not statistically significant at the $95 \%$ level using a $t$ test are assigned a value of zero.

than biological productivity (which has a much larger impact on DIC than Alk), in $\mathrm{CO}_{2}$ flux predictability.

\subsection{Predictive skill}

We next evaluate the predictive skill of the CESM-DPLE forecasts; the skill is a measure of the ability of the forecast to reproduce the observational record. For air-sea $\mathrm{CO}_{2}$ flux, direct observations are rare, and we are constrained to estimates of flux from observations of sparsely sampled surface ocean $p \mathrm{CO}_{2}$. Here, we use as our observational metric the $\mathrm{CO}_{2}$ flux estimated from the Landschützer et al. (2016) surface ocean $p \mathrm{CO}_{2}$ product. This product is a gap-filled estimate of surface ocean $p \mathrm{CO}_{2}$, which, when combined with measurements of atmospheric $p \mathrm{CO}_{2}$, sea surface temperature, salinity, and wind, yields a monthly estimate of air-sea $\mathrm{CO}_{2}$ flux at $1^{\circ} \times 1^{\circ}$ horizontal resolution from 1982-2015 (see also Fig. 2a). As the $p \mathrm{CO}_{2}$ observations are rather sparse prior to 1995 (see Fig. 2 of Bakker et al., 2016), we calculate skill for the period between 1995 and 2015 only, but show for the interested reader the full observational product time series.

The CESM-DPLE initialized predictions exhibit some skill at representing the globally integrated air-sea $\mathrm{CO}_{2}$ flux in forecast lead year 1 (Fig. 3a and b; initialized forecast skill 0.88 ; detrended, initialized forecast skill 0.66). Our comparison indicates that CESM-DPLE (and the reconstruction, for that matter) struggles to produce the pronounced trends toward anomalous $\mathrm{CO}_{2}$ outgassing in the 1990s and anomalous $\mathrm{CO}_{2}$ uptake in the 2000s. The ability (or lack thereof) of ESMs to reproduce the observationally derived multidecadal air-sea $\mathrm{CO}_{2}$ flux variability has been the subject of recent publications (e.g., Li and Ilyina, 2018; Gruber et al., 2019), though no robust mechanisms seem to explain the (mis)match. The CESM-DPLE initialized forecast in forecast lead year 1 exhibits moderate predictive skill in the tropics and subtropics (Fig. 7) and low skill elsewhere.

\subsection{Predictability and predictive skill on the biome scale}

Because the predictability of air-sea $\mathrm{CO}_{2}$ flux is primarily driven by the predictability of the biogeochemical state variables DIC and Alk, it makes sense to aggregate predictability across biogeographical biomes. We probe the limits of predictability and predictive skill in regional air-sea $\mathrm{CO}_{2}$ flux by averaging the local flux across 17 biogeographical biomes. This is achieved by re-gridding the Fay and McKinley (2014) mean biome mask to the CESM model grid and computing the area-weighted average $\mathrm{CO}_{2}$ flux from the reconstruction, CESM-DPLE initialized forecasts, and observationally derived $p \mathrm{CO}_{2}$ product. The detrended $\mathrm{CO}_{2}$ flux anomalies for three of the biomes are shown for forecast lead year 1 in Fig. 8, and the predictability and predictive skill across all biomes is detailed in Table 1. These three biomes were chosen to contrast their predictability and/or predictive skill.

The biome-averaged $\mathrm{CO}_{2}$ flux anomalies from the CESMDPLE initialized forecast in forecast lead year 1 exhibit high correlations with the reconstruction anomalies in the North Pacific subtropical biomes and in the Southern Ocean ice biome (Fig. 8; Table 1), indicating high potential for the prediction of $\mathrm{CO}_{2}$ flux anomalies. This predictability decreases with increasing forecast lead time in the North Pacific subtropical biomes, but persists for the Southern Ocean ice biome through forecast years 7-9 (Fig. 8). Indeed, the Southern Ocean ice biome is an anomaly in this regard; in the other 16 biomes, predictability drops off with prediction lead time (not shown).

Initialization engenders the predictability of air-sea $\mathrm{CO}_{2}$ flux variability the North Pacific subtropical biomes, as we find low correlation between the uninitialized CESM-LE forecast $\mathrm{CO}_{2}$ flux anomalies and the reconstruction anomalies here (Fig. 8a and b; Table 1). The initialized forecast for these biomes has higher predictability than the uninitialized forecast and the persistence forecast for 7-8 years (Fig. 9). These conclusions hold for most of the other ocean biomes (Table 1), with a few exceptions for which the uninitialized forecast and/or persistence forecast are similar to the initial- 


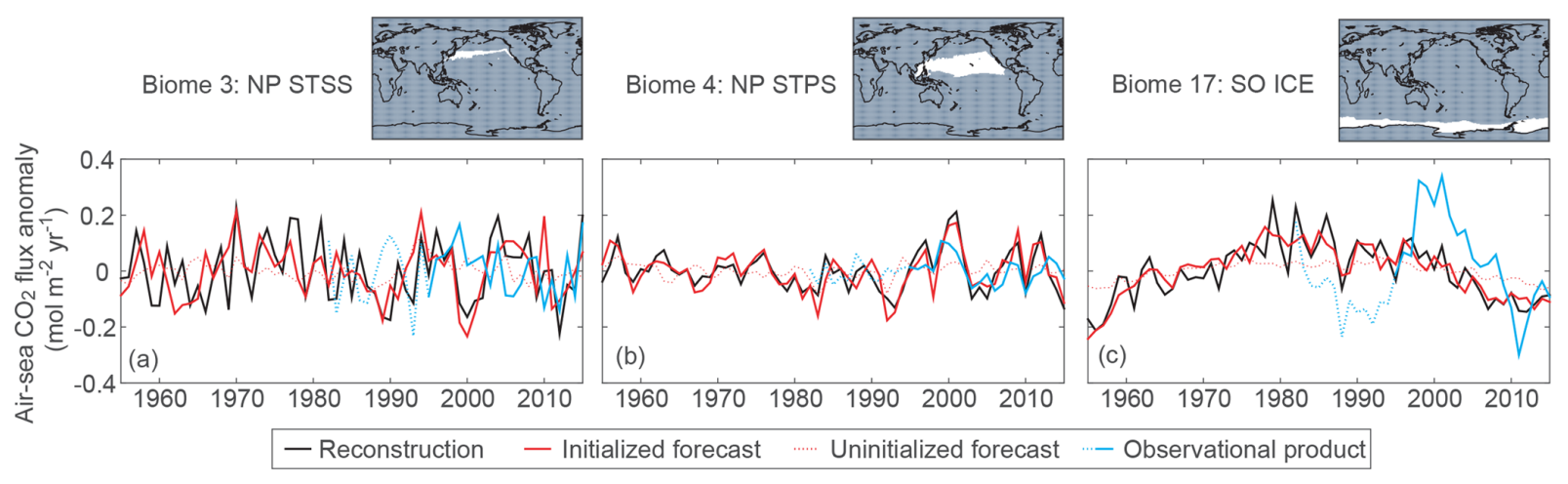

Figure 8. Temporal evolution of the biome-averaged air-sea $\mathrm{CO}_{2}$ flux anomalies in the (a) NP STSS, (b) NP STPS, and (c) SO ICE biomes $\left(\mathrm{mol} \mathrm{m}^{-2} \mathrm{yr}^{-1}\right.$ ). The following time series are plotted: (black) reconstruction, (red) CESM-DPLE initialized forecast, (red dotted) CESMLE uninitialized forecast, and (blue) Landschützer et al. (2016) observationally based product. The CESM-DPLE time series is the linearly detrended, drift-corrected, ensemble mean forecast anomalies in year 1; the reconstruction, CESM-LE ensemble mean, and observed time series have been transformed to anomalies by removing the linear trend. Observations prior to 1995 are dotted due to lower observation density. Positive anomalies indicate anomalous ocean outgassing.

(a) Biome 3: NP STSS

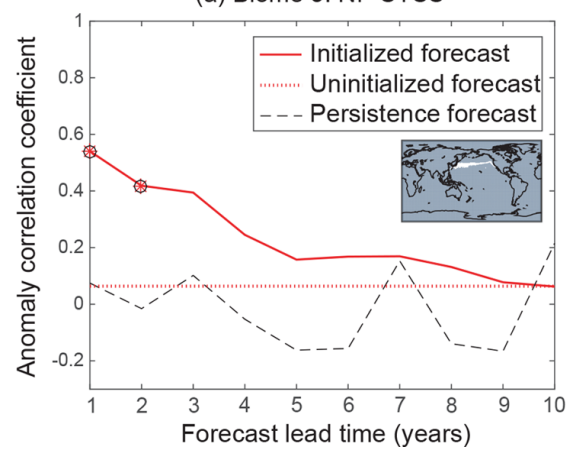

(b) Biome 4: NP STPS

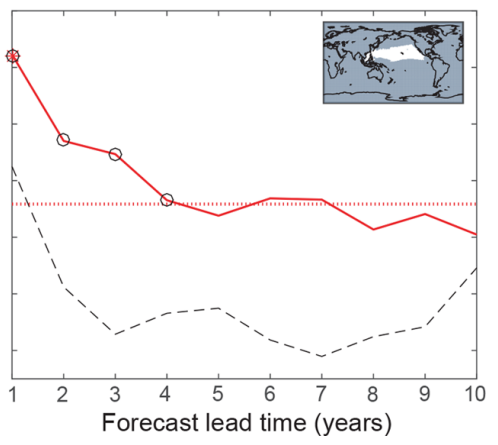

(c) Biome 17: SO ICE

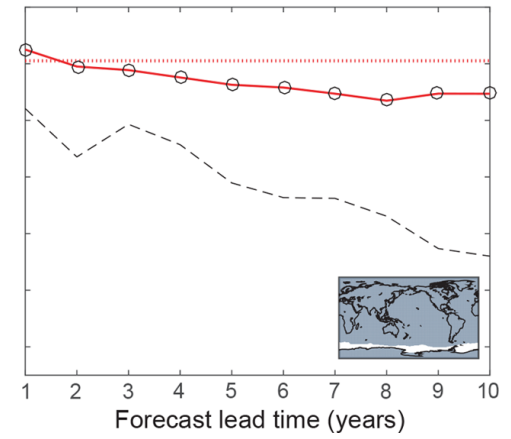

Figure 9. Predictability of biome-averaged $\mathrm{CO}_{2}$ flux as a function of lead time in the (a) NP STSS, (b) NP STPS, and (c) SO ICE biomes, as indicated by the correlation coefficient of detrended $\mathrm{CO}_{2}$ flux anomalies from the (red) CESM-DPLE initialized forecast and the (red dotted) CESM-LE uninitialized forecast with the reconstruction. The black dashed line shows the correlation coefficient of the persistence forecast as a function of lead time. Red asterisks (black circles) on the initialized forecast indicate predictability that is statistically different from the initialized (persistence) forecast at the $95 \%$ level using a $z$ test.

ized forecast (e.g., the eastern Pacific equatorial biome). In the Southern Ocean ice biome, the $\mathrm{CO}_{2}$ flux predictability is almost entirely driven by external forcing, and the persistence forecast indicates high predictability as well (Figs. 8 and 9, Table 1). Thus, the high and long-lasting predictability in this biome must be interpreted with caution given the importance of external forcing in predicting $\mathrm{CO}_{2}$ flux anomalies here.

The predictive skill of CESM-DPLE in forecast lead year 1 is illustrated for three biomes in Fig. 8 and Table 1. Again, we note the moderate skill in the tropics and subtropics and lower skill elsewhere.

The difference in the predictability between the initialized, uninitialized, and persistence forecasts reveals the impact of initialization on predictions of air-sea $\mathrm{CO}_{2}$ flux variability on the biome scale (Fig. 9). We probe the limits of initialized predictability in each biome by calculating the max- imum forecast lead time for which the initialized CESMDPLE $\mathrm{CO}_{2}$ flux forecast has both higher predictability than the uninitialized CESM-LE and persistence forecasts and present the results in Fig. 10. Our results indicate that initialization improves the forecast for the longest lead times in the subantarctic Southern Ocean and the northern North Atlantic, where the initialized forecast beats the other two forecasts out to forecast lead times of 10 and 9 years, respectively. We note, however, that the improvement in the North Atlantic is only statistically significant for 1 lead year and in the Southern Ocean for 2-3 lead years. Given the important role of these two regions for the global ocean uptake of anthropogenic carbon, and the numerous studies linking climate variability to air-sea $\mathrm{CO}_{2}$ flux variability in these regions, this long-lasting predictability is encouraging. In other regions, however, such as the Southern Ocean ice or eastern equatorial Pacific biomes, the initialized forecast only beats 
Table 1. Biome-averaged air-sea $\mathrm{CO}_{2}$ flux statistics.

\begin{tabular}{|c|c|c|c|c|c|c|c|}
\hline $\begin{array}{l}\text { Biome } \\
\text { name }\end{array}$ & $\begin{array}{l}\text { Biome } \\
\text { acronym }\end{array}$ & $\begin{array}{l}\text { Biome } \\
\text { number }\end{array}$ & $\begin{array}{l}\text { Initialized } \\
\text { forecast }^{\mathrm{a}}\end{array}$ & $\begin{array}{l}\text { Uninitialized } \\
\text { forecast }^{\mathrm{b}}\end{array}$ & $\begin{array}{l}\text { Persistence } \\
\text { forecast }^{c}\end{array}$ & $\begin{array}{l}\text { Forecast } \\
\text { skill }^{\mathrm{d}}\end{array}$ & $\begin{array}{l}\text { Maximum } \\
\text { lead time }\end{array}$ \\
\hline North Pacific ice & NP ICE & 1 & 0.29 & -0.22 & 0.25 & 0.43 & $3(0)$ \\
\hline $\begin{array}{l}\text { North Pacific subpolar } \\
\text { Seasonally stratified }\end{array}$ & NP SPSS & 2 & 0.54 & -0.12 & 0.47 & -0.45 & $2(0)$ \\
\hline $\begin{array}{l}\text { North Pacific subtropical } \\
\text { Seasonally stratified }\end{array}$ & NP STSS & 3 & 0.54 & 0.06 & 0.07 & -0.28 & $9(2)$ \\
\hline $\begin{array}{l}\text { North Pacific subtropical } \\
\text { Permanently stratified }\end{array}$ & NP STPS & 4 & 0.85 & 0.32 & 0.45 & 0.60 & $4(1)$ \\
\hline West Pacific equatorial & PEQU-W & 5 & 0.73 & 0.31 & 0.52 & 0.66 & $5(0)$ \\
\hline East Pacific equatorial & PEQU-E & 6 & 0.64 & 0.35 & 0.50 & 0.53 & $1(0)$ \\
\hline $\begin{array}{l}\text { South Pacific subtropical } \\
\text { Permanently stratified }\end{array}$ & SP STPS & 7 & 0.81 & 0.33 & 0.50 & 0.19 & $3(1)$ \\
\hline North Atlantic ice & NA ICE & 8 & 0.49 & 0.07 & 0.24 & 0.36 & $4(0)$ \\
\hline $\begin{array}{l}\text { North Atlantic subpolar } \\
\text { Seasonally stratified }\end{array}$ & NA SPSS & 9 & 0.55 & 0.10 & 0.17 & -0.28 & $9(1)$ \\
\hline $\begin{array}{l}\text { North Atlantic subtropical } \\
\text { Seasonally stratified }\end{array}$ & NA STSS & 10 & 0.53 & -0.08 & 0.01 & -0.10 & $9(1)$ \\
\hline $\begin{array}{l}\text { North Atlantic subtropical } \\
\text { Permanently stratified }\end{array}$ & NA STPS & 11 & 0.72 & 0.35 & 0.18 & 0.56 & $3(1)$ \\
\hline Atlantic equatorial & AEQU & 12 & 0.55 & 0.17 & 0.27 & -0.04 & $4(1)$ \\
\hline $\begin{array}{l}\text { South Atlantic subtropical } \\
\text { Permanently stratified }\end{array}$ & SA STPS & 13 & 0.60 & 0.09 & 0.16 & 0.49 & $2(1)$ \\
\hline $\begin{array}{l}\text { Indian Ocean subtropical } \\
\text { Permanently stratified }\end{array}$ & IND STPS & 14 & 0.16 & -0.11 & 0.05 & 0.31 & $3(2)$ \\
\hline $\begin{array}{l}\text { Southern Ocean subtropical } \\
\text { Seasonally stratified }\end{array}$ & SO STSS & 15 & 0.70 & -0.02 & 0.20 & 0.26 & $10(3)$ \\
\hline $\begin{array}{l}\text { Southern Ocean subpolar } \\
\text { Seasonally stratified }\end{array}$ & SO SPSS & 16 & 0.47 & 0.08 & 0.32 & 0.47 & $10(2)$ \\
\hline Southern Ocean ice & SO ICE & 17 & 0.85 & 0.81 & 0.64 & 0.60 & $1(0)$ \\
\hline
\end{tabular}

the uninitialized or persistence forecast for a single year, indicating little benefit of forecast initialization for $\mathrm{CO}_{2}$ flux forecasts here.

\section{Conclusions}

We analyze output from the CESM-DPLE system to quantify and understand the sources of predictability and predictive skill in global and regional air-sea $\mathrm{CO}_{2}$ flux on annual to decadal timescales. We find high potential predictability in globally integrated $\mathrm{CO}_{2}$ flux several years in advance that is engendered by initialization. This potential predictability is evident across much of the global ocean, driven by predictability in $\triangle p \mathrm{CO}_{2}$, which itself is primarily driven by predictability in surface ocean DIC and Alk. While the CESMDPLE system exhibits strong potential predictability, model skill as compared to an observationally based product remains a challenge to developing useful forecasts.
Our study complements two recent studies of ocean carbon decadal predictions conducted at different modeling centers. Li et al. (2016) use decadal predictions from MPIESM to investigate near-term changes in North Atlantic $\mathrm{CO}_{2}$ flux, while Séférian et al. (2018) use CNRM-ESM1 to assess the predictability horizon of globally integrated ocean and land carbon fluxes. While these studies use different prediction systems, we nevertheless come to some of the same conclusions. For example, Séférian et al. (2018) find that global ocean carbon uptake is potentially predictable for up to 6 years, and $\mathrm{Li}$ et al. (2016) find high potential predictability in the North Atlantic that is engendered by initialization. These studies collectively suggest predictability for near-term ocean carbon uptake on global and regional scales, which is beneficial for forecasting the future global carbon budget and climate system.

While the ever-expanding field of decadal climate prediction has the potential to inform policy and management de- 


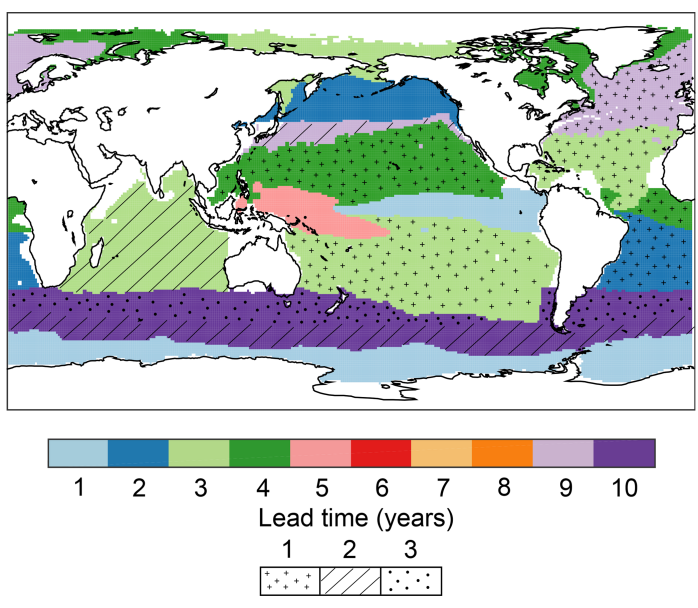

Figure 10. For each biome, the maximum forecast lead time (years) in which the initialized CESM-DPLE $\mathrm{CO}_{2}$ flux forecast has both higher predictability than the uninitialized CESM-LE forecast and a higher correlation coefficient than the persistence forecast. Hatching shows the maximum forecast lead time while accounting for statistical separation of correlation coefficients at the $95 \%$ level using a $z$ test.

cisions moving forward, decadal forecasts come with several caveats. Initialization shock and drift of the coupled model system, the inability of Earth system models to realistically simulate internal variability, uncertain future levels of radiative forcing, and imperfect observations are frequently cited as limitations to making accurate forecasts of the future (Meehl et al., 2014). In the case of ocean carbon, it is important to note that potential predictability in regional $\mathrm{CO}_{2}$ flux may be driven by initialization of the physical (e.g., SST) or biogeochemical (e.g., DIC) ocean state (Li et al., 2016) and that the spatiotemporal coverage of $\mathrm{CO}_{2}$ flux observations is insufficient to fully address predictive skill in our forecast systems.

Data availability. The CESM simulation data analyzed in this paper are available from the project web pages of the CESM Large Ensemble (http://www.cesm.ucar.edu/projects/ community-projects/LENS/, CESM Projects, 2019) and the CESM Decadal Prediction Large Ensemble (http://www.cesm.ucar.edu/ projects/community-projects/DPLE/, DPLE, 2019).

Supplement. The supplement related to this article is available online at: https://doi.org/10.5194/esd-10-45-2019-supplement.

Author contributions. SGY led the CESM-DPLE forecasting effort. NSL analyzed the model output and drafted the paper. All authors were involved with the study design, discussed the results, and contributed to writing the paper.
Competing interests. The authors declare that they have no conflict of interest.

Acknowledgements. The CESM-DPLE was generated using computational resources provided by the National Energy Research Scientific Computing Center, which is supported by the Office of Science of the US Department of Energy under contract no. DEAC02-05CH11231, as well as by an Accelerated Scientific Discovery grant for Cheyenne (https://doi.org/10.5065/D6RX99HX) that was awarded by NCAR's Computational and Information Systems Laboratory. The NCAR contribution to this study was supported by the National Oceanic and Atmospheric Administration Climate Program Office under Climate Variability and Predictability Program grant NA09OAR4310163, the National Science Foundation (NSF) Collaborative Research EaSM2 grant OCE-1243015, and the NSF through its sponsorship of NCAR. Nicole S. Lovenduski is grateful for funding from the NSF (OCE-1752724, OCE-1558225).

Edited by: Christoph Heinze

Reviewed by: two anonymous referees

\section{References}

Bakker, D. C. E., Pfeil, B., Landa, C. S., Metzl, N., O’Brien, K. M., Olsen, A., Smith, K., Cosca, C., Harasawa, S., Jones, S. D., Nakaoka, S.-I., Nojiri, Y., Schuster, U., Steinhoff, T., Sweeney, C., Takahashi, T., Tilbrook, B., Wada, C., Wanninkhof, R., Alin, S. R., Balestrini, C. F., Barbero, L., Bates, N. R., Bianchi, A. A., Bonou, F., Boutin, J., Bozec, Y., Burger, E. F., Cai, W.-J., Castle, R. D., Chen, L., Chierici, M., Currie, K., Evans, W., Featherstone, C., Feely, R. A., Fransson, A., Goyet, C., Greenwood, N., Gregor, L., Hankin, S., Hardman-Mountford, N. J., Harlay, J., Hauck, J., Hoppema, M., Humphreys, M. P., Hunt, C. W., Huss, B., Ibánhez, J. S. P., Johannessen, T., Keeling, R., Kitidis, V., Körtzinger, A., Kozyr, A., Krasakopoulou, E., Kuwata, A., Landschützer, P., Lauvset, S. K., Lefèvre, N., Lo Monaco, C., Manke, A., Mathis, J. T., Merlivat, L., Millero, F. J., Monteiro, P. M. S., Munro, D. R., Murata, A., Newberger, T., Omar, A. M., Ono, T., Paterson, K., Pearce, D., Pierrot, D., Robbins, L. L., Saito, S., Salisbury, J., Schlitzer, R., Schneider, B., Schweitzer, R., Sieger, R., Skjelvan, I., Sullivan, K. F., Sutherland, S. C., Sutton, A. J., Tadokoro, K., Telszewski, M., Tuma, M., van Heuven, S. M. A. C., Vandemark, D., Ward, B., Watson, A. J., and Xu, S.: A multidecade record of high-quality $f \mathrm{CO}_{2}$ data in version 3 of the Surface Ocean $\mathrm{CO}_{2}$ Atlas (SOCAT), Earth Syst. Sci. Data, 8, 383413, https://doi.org/10.5194/essd-8-383-2016, 2016.

Boer, G. J., Kharin, V. V., and Merryfield, W. J.: Decadal predictability and forecast skill, Clim. Dynam., 41, 1817-1833, https://doi.org/10.1007/s00382-013-1705-0, 2013.

Boer, G. J., Smith, D. M., Cassou, C., Doblas-Reyes, F., Danabasoglu, G., Kirtman, B., Kushnir, Y., Kimoto, M., Meehl, G. A., Msadek, R., Mueller, W. A., Taylor, K. E., Zwiers, F., Rixen, M., Ruprich-Robert, Y., and Eade, R.: The Decadal Climate Prediction Project (DCPP) contribution to CMIP6, Geosci. Model Dev., 9, 3751-3777, https://doi.org/10.5194/gmd-9-3751-2016, 2016.

Breeden, M. L. and McKinley, G. A.: Climate impacts on multidecadal $p \mathrm{CO}_{2}$ variability in the North Atlantic: 1948-2009, 
Biogeosciences, 13, 3387-3396, https://doi.org/10.5194/bg-133387-2016, 2016.

CESM Projects: LENS, http://www.cesm.ucar.edu/projects/ community-projects/LENS/, last access: 22 January 2019.

Ciais, P. and Sabine, C.: Chapter 6: Carbon and Other Biogeochemical Cycles, in: Climate Change 2013: The Physical Science Basis, Contribution of Working Group I to the Fifth Assessment Report of the Intergovernmental Panel on Climate Change, edited by: Stocker, T. F., Qin, D., Plattner, G.-K., Tignor, M. M. B., Allen, S. K., Boschung, J., Nauels, A., Xia, Y., Bex, V., and Midgley, P. M., Cambridge University Press, Cambridge, UK and New York, NY, USA, 1535 pp., 2013.

Danabasoglu, G., Bates, S. C., Briegleb, B. P., Jayne, S. R., Jochum, M., Large, W. G., Peacock, S., and Yeager, S. G.: The CCSM4 Ocean Component, J. Climate, 25, 1361-1389, 2012.

Doney, S. C., Lindsay, K., Fung, I., and John, J.: Natural Variability in a Stable, 1000-Yr Global Coupled ClimateCarbon Cycle Simulation, J. Climate, 19, 3033-3054, https://doi.org/10.1175/JCLI3783.1, 2006.

Doney, S. C., Lima, I., Feely, R. A., Glover, D. M., Lindsay, K., Mahowald, N., Moore, J. K., and Wanninkhof, R.: Mechanisms governing interannual variability in upper-ocean inorganic carbon system and air-sea $\mathrm{CO}_{2}$ fluxes: Physical climate and atmospheric dust, Deep-Sea Res. Pt. II, 56, 640-655, 2009.

DPLE: Decadal Prediction Large Ensemble, http://www.cesm.ucar. edu/projects/community-projects/DPLE/, last access: 22 January 2019.

Fay, A. R. and McKinley, G. A.: Global open-ocean biomes: mean and temporal variability, Earth Syst. Sci. Data, 6, 273-284, https://doi.org/10.5194/essd-6-273-2014, 2014.

Fay, A. R., McKinley, G. A., and Lovenduski, N. S.: Southern Ocean carbon trends: Sensitivity to methods, Geophys. Res. Lett., 41, 6833-6840, https://doi.org/10.1002/2014GL061324, 2014.

Freeman, N. M., Lovenduski, N. S., Munro, D. R., Krumhardt, K. M., Lindsay, K., Long, M. C., and Maclennan, M.: The Variable and Changing Southern Ocean Silicate Front: Insights From the CESM Large Ensemble, Global Biogeochem. Cy., 32, 752-768, https://doi.org/10.1029/2017GB005816, 2018.

Gruber, N., Landschützer, P., and Lovenduski, N. S.: The Variable Southern Ocean Carbon Sink, Annu. Rev. Mar. Sci., 11, 159-186, https://doi.org/10.1146/annurev-marine-121916$063407,2019$.

Hauck, J., Völker, C., Wang, T., Hoppema, M., Losch, M., and Wolf-Gladrow, D. A.: Seasonally different carbon flux changes in the Southern Ocean in response to the Southern Annular Mode, Global Biogeochem. Cy., 27, 1236-1245, https://doi.org/10.1002/2013GB004600, 2013.

Hunke, E. C. and Lipscomb, W. H.: CICE: the Los Alamos sea ice model user's manual, version 4, Los Alamos Natl. Lab. Tech. Report, LA-CC-06-012, Los Alamos Natl. Lab., Los Alamos, NM, USA, 2008.

Hurrell, J. W., Holland, M. M., Gent, P. R., Ghan, S., Kay, J. E., Kushner, P. J., Lamarque, J. F., Large, W. G., Lawrence, D., Lindsay, K., Lipscomb, W. H., Long, M. C., Mahowald, N., Marsh, D. R., Neale, R. B., Rasch, P., Vavrus, S., Vertenstein, M., Bader, D., Collins, W. D., Hack, J. J., Kiehl, J., and Marshall, S.: The Community Earth System Model: A Framework for Collaborative Research, B. Am. Meteorol. Soc., 94, 13391360, https://doi.org/10.1175/BAMS-D-12-00121.1, 2013.

Kay, J. E., Deser, C., Phillips, A., Mai, A., Hannay, C., Strand, G., Arblaster, J. M., Bates, S. C., Danabasoglu, G., Edwards, J., Holland, M., Kushner, P., Lamarque, J. F., Lawrence, D., Lindsay, K., Middleton, A., Munoz, E., Neale, R., Oleson, K., Polvani, L., and Vertenstein, M.: The Community Earth System Model (CESM) Large Ensemble project: A community resource for studying climate change in the presence of internal climate variability, B. Am. Meteorol. Soc., 96, 1333-1349, https://doi.org/10.1175/BAMS-D-13-00255.1, 2015.

Keenlyside, N. S., Latif, M., Jungclaus, J., Kornblueh, L., and Roeckner, E.: Advancing decadal-scale climate prediction in the North Atlantic sector, Nature, 453, 84-88, https://doi.org/10.1038/nature06921, 2008.

Kirtman, B., Power, S. B., Adedoyin, J. A., Boer, G. J., Bojariu, R., Camilloni, I., Doblas-Reyes, F. J., Fiore, A. M., Kimoto, M., Meehl, G. A., Prather, M., Sarr, A., Schär, C., Sutton, R., van Oldenborgh, G. J., Vecchi, G., and Wang, H. J.: Nearterm Climate Change: Projections and Predictability, in: Climate Change 2013: The Physical Science Basis, Contribution of Working Group I to the Fifth Assessment Report of the Intergovernmental Panel on Climate Change, edited by: Stocker, T. F., Qin, D., Plattner, G. K., Tignor, M., Allen, S. K., Boschung, J., Nauels, A., Xia, Y., Bex, V., and Midgley, P. M., Cambridge University Press, Cambridge, 2013.

Krumhardt, K. M., Lovenduski, N. S., Long, M. C., and Lindsay, K.: Avoidable impacts of ocean warming on marine primary production: Insights from the CESM ensembles, Global Biogeochem. Cy., 31, 114-133, https://doi.org/10.1002/2016GB005528, 2017.

Landschützer, P., Gruber, N., Haumann, F. A., Rödenbeck, C., Bakker, D. C. E., van Heuven, S., Hoppema, M., Metzl, N., Sweeney, C., Takahashi, T., Tilbrook, B., and Wanninkhof, R.: The reinvigoration of the Southern Ocean carbon sink, Science, 349, 1221-1224, 2015.

Landschützer, P., Gruber, N., and Bakker, D. C. E.: Decadal variations and trends of the global ocean carbon sink, Global Biogeochem. Cy., 30, 1396-1417, https://doi.org/10.1002/2015GB005359, 2016.

Lawrence, D. M., Oleson, K. W., Flanner, M. G., Fletcher, C. G., Lawrence, P. J., Levis, S., Swenson, S. C., and Bonan, G. B.: The CCSM4 Land Simulation, 1850-2005: Assessment of Surface Climate and New Capabilities, J. Climate, 25, 2240-2260, https://doi.org/10.1175/JCLI-D-11-00103.1, 2012.

Lenton, A. and Matear, R. J.: Role of the Southern Annular Mode (SAM) in Southern Ocean $\mathrm{CO}_{2}$ uptake, Global Biogeochem. Cy., 21, GB2016, https://doi.org/10.1029/2006GB002714, 2007.

Lenton, A., Tilbrook, B., Law, R. M., Bakker, D., Doney, S. C., Gruber, N., Ishii, M., Hoppema, M., Lovenduski, N. S., Matear, R. J., McNeil, B. I., Metzl, N., Mikaloff Fletcher, S. E., Monteiro, P. M. S., Rödenbeck, C., Sweeney, C., and Takahashi, T.: Seaair $\mathrm{CO}_{2}$ fluxes in the Southern Ocean for the period 1990-2009, Biogeosciences, 10, 4037-4054, https://doi.org/10.5194/bg-104037-2013, 2013.

Le Quéré, C., Andrew, R. M., Friedlingstein, P., Sitch, S., Pongratz, J., Manning, A. C., Korsbakken, J. I., Peters, G. P., Canadell, J. G., Jackson, R. B., Boden, T. ., Tans, P. P., Andrews, O. D., Arora, V. K., Bakker, D. C. E., Barbero, L., Becker, M., Betts, R. 
A., Bopp, L., Chevallier, F., Chini, L. P., Ciais, P., Cosca, C. E., Cross, J., Currie, K., Gasser, T., Harris, I., Hauck, J., Haverd, V., Houghton, R. A., Hunt, C. W., Hurtt, G., Ilyina, T., Jain, A. K., Kato, E., Kautz, M., Keeling, R. F., Klein Goldewijk, K., Körtzinger, A., Landschützer, P., Lefèvre, N., Lenton, A., Lienert, S., Lima, I., Lombardozzi, D., Metzl, N., Millero, F., Monteiro, P. M. S., Munro, D. R., Nabel, J. E. M. S., Nakaoka, S.-I., Nojiri, Y., Padin, X. A., Peregon, A., Pfeil, B., Pierrot, D., Poulter, B., Rehder, G., Reimer, J., Rödenbeck, C., Schwinger, J., Séférian, R., Skjelvan, I., Stocker, B. D., Tian, H., Tilbrook, B., Tubiello, F. N., van der Laan-Luijkx, I. T., van der Werf, G. R., van Heuven, S., Viovy, N., Vuichard, N., Walker, A. P., Watson, A. J., Wiltshire, A. J., Zaehle, S., and Zhu, D.: Global Carbon Budget 2017, Earth Syst. Sci. Data, 10, 405-448, https://doi.org/10.5194/essd-10-405-2018, 2018.

Li, H. and Ilyina, T.: Current and Future Decadal Trends in the Oceanic Carbon Uptake Are Dominated by Internal Variability, Geophys. Res. Lett., 45, 916-925, https://doi.org/10.1002/2017GL075370, 2018.

Li, H., Ilyina, T., Müller, W. A., and Sienz, F.: Decadal predictions of the North Atlantic $\mathrm{CO}_{2}$ uptake, Nat. Commun., 7, 11076, https://doi.org/10.1038/ncomms11076, 2016.

Long, M. C., Lindsay, K., Peacock, S., Moore, J. K., and Doney, S. C.: Twentieth-Century Oceanic Carbon Uptake and Storage in CESM1(BGC), J. Climate, 26, 6775-6800, https://doi.org/10.1175/JCLI-D-12-00184.1, 2013.

Long, M. C., Deutsch, C., and Ito, T.: Finding forced trends in oceanic oxygen, Global Biogeochem. Cy., 30, 381-397, https://doi.org/10.1002/2015GB005310, 2016.

Lovenduski, N. S., Gruber, N., Doney, S. C., and Lima, I. D.: Enhanced $\mathrm{CO}_{2}$ outgassing in the Southern Ocean from a positive phase of the Southern Annular Mode, Global Biogeochem. Cy., 21, GB2026, https://doi.org/10.1029/2006GB002900, 2007.

Lovenduski, N. S., Long, M. C., Gent, P. R., and Lindsay, K.: Multi-decadal trends in the advection and mixing of natural carbon in the Southern Ocean, Geophys. Res. Lett., 40, 139-142, https://doi.org/10.1029/2012GL054483, 2013.

Lovenduski, N. S., Fay, A. R., and McKinley, G. A.: Observing multidecadal trends in Southern Ocean $\mathrm{CO}_{2}$ uptake: What can we learn from an ocean model?, Global Biogeochem. Cy., 29, 416-426, https://doi.org/10.1002/2014GB004933, 2015a.

Lovenduski, N. S., Long, M. C., and Lindsay, K.: Natural variability in the surface ocean carbonate ion concentration, Biogeosciences, 12, 6321-6335, https://doi.org/10.5194/bg-12-63212015, 2015b.

Lovenduski, N. S., McKinley, G. A., Fay, A. R., Lindsay, K., and Long, M. C.: Partitioning uncertainty in ocean carbon uptake projections: Internal variability, emission scenario, and model structure, Global Biogeochem. Cy., 30, 1276-1287, https://doi.org/10.1002/2016GB005426, 2016.

McKinley, G. A., Pilcher, D. J., Fay, A. R., Lindsay, K., Long, M. C., and Lovenduski, N. S.: Timescales for detection of trends in the ocean carbon sink, Nature, 530, 469-472, 2016.

McKinley, G. A., Fay, A. R., Lovenduski, N. S., and Pilcher, D. J.: Natural Variability and Anthropogenic Trends in the Ocean Carbon Sink, Annu. Rev. Mar. Sci., 9, 125-150, https://doi.org/10.1146/annurev-marine-010816-060529, 2017.

Meehl, G. A., Goddard, L., Murphy, J., Stouffer, R. J., Boer, G., Danabasoglu, G., Dixon, K., Giorgetta, M. A., Greene,
A. M., Hawkins, E., Hegerl, G., Karoly, D., Keenlyside, N., Kimoto, M., Kirtman, B., Navarra, A., Pulwarty, R., Smith, D., Stammer, D., and Stockdale, T.: Decadal prediction: Can it be skillful?, B. Am. Meteorol. Soc., 90, 1467-1485, https://doi.org/10.1175/2009BAMS2778.1, 2009.

Meehl, G. A., Goddard, L., Boer, G., Burgman, R., Branstator, G., Cassou, C., Corti, S., Danabasoglu, G., Doblas-Reyes, F., Hawkins, E., Karspeck, A., Kimoto, M., Kumar, A., Matei, D., Mignot, J., Msadek, R., Navarra, A., Pohlmann, H., Rienecker, M., Rosati, T., Schneider, E., Smith, D., Sutton, R., Teng, H., van Oldenborgh, G. J., Vecchi, G., and Yeager, S.: Decadal Climate Prediction: An Update from the Trenches, B. Am. Meteorol. Soc., 95, 243-267, https://doi.org/10.1175/BAMS-D-12$00241.1,2014$.

Metzl, N., Corbière, A., Reverdin, G., Lenton, A., Takahashi, T., Olsen, A., Johannessen, T., Pierrot, D., Wanninkhof, R., Ólafsdóttir, S. R., Olafsson, J., and Ramonet, M.: Recent acceleration of the sea surface $f \mathrm{CO}_{2}$ growth rate in the North Atlantic subpolar gyre (1993-2008) revealed by winter observations, Global Biogeochem. Cy., 24, GB4004, https://doi.org/10.1029/2009GB003658, 2010.

Moore, J. K. and Braucher, O.: Sedimentary and mineral dust sources of dissolved iron to the world ocean, Biogeosciences, 5, 631-656, https://doi.org/10.5194/bg-5-631-2008, 2008.

Moore, J. K., Doney, S. C., and Lindsay, K.: Upper ocean ecosystem dynamics and iron cycling in a global threedimensional model, Global Biogeochem. Cy., 18, GB4028, https://doi.org/10.1029/2004GB002220, 2004.

Moore, J. K., Lindsay, K., Doney, S. C., Long, M. C., and Misumi, K.: Marine Ecosystem Dynamics and Biogeochemical Cycling in the Community Earth System Model [CESM1(BGC)]: Comparison of the 1990s with the 2090s under the RCP4.5 and RCP8.5 Scenarios, J. Climate, 26, 9291-9312, https://doi.org/10.1175/JCLI-D-12-00566.1, 2013.

Munro, D. R., Lovenduski, N. S., Takahashi, T., Stephens, B. B., Newberger, T., and Sweeney, C.: Recent evidence for a strengthening $\mathrm{CO}_{2}$ sink in the Southern Ocean from carbonate system measurements in the Drake Passage (2002-2015), Geophys. Res. Lett., 42, 7623-7630, https://doi.org/10.1002/2015GL065194, 2015.

Resplandy, L., Séférian, R., and Bopp, L.: Natural variability of $\mathrm{CO}_{2}$ and $\mathrm{O}_{2}$ fluxes: What can we learn from centuries-long climate models simulations?, J. Geophys. Res.-Oceans, 120, 384 404, https://doi.org/10.1002/2014JC010463, 2015.

Robson, J. I., Sutton, R. T., and Smith, D. M.: Initialized decadal predictions of the rapid warming of the North Atlantic Ocean in the mid 1990s, Geophys. Res. Lett., 39, 119713, https://doi.org/10.1029/2012GL053370, 2012.

Rödenbeck, C., Bakker, D. C. E., Gruber, N., Iida, Y., Jacobson, A. R., Jones, S., Landschützer, P., Metzl, N., Nakaoka, S., Olsen, A., Park, G.-H., Peylin, P., Rodgers, K. B., Sasse, T. P., Schuster, U., Shutler, J. D., Valsala, V., Wanninkhof, R., and Zeng, J.: Data-based estimates of the ocean carbon sink variability - first results of the Surface Ocean $p \mathrm{CO}_{2}$ Mapping intercomparison (SOCOM), Biogeosciences, 12, 72517278, https://doi.org/10.5194/bg-12-7251-2015, 2015.

Séférian, R., Berthet, S., and Chevallier, M.: Assessing the Decadal Predictability of Land and Ocean Carbon Uptake, Geophys. Res. 
Lett., 45, 2455-2466, https://doi.org/10.1002/2017GL076092, 2018.

Smith, D. M., Cusack, S., Colman, A. W., Folland, C. K., Harris, G. R., and Murphy, J. M.: Improved Surface Temperature Prediction for the Coming Decade from a Global Climate Model, Science, 317, 796-799, https://doi.org/10.1126/science.1139540, 2007.

Thomas, H., Friederike Prowe, A. E., Lima, I. D., Doney, S. C., Wanninkhof, R., Greatbatch, R. J., Schuster, U., and Corbiére, A.: Changes in the North Atlantic Oscillation influence $\mathrm{CO}_{2}$ uptake in the North Atlantic over the past 2 decades, Global Biogeochem. Cy., 22, GB4027, https://doi.org/10.1029/2007GB003167, 2008.

Ullman, D. J., McKinley, G. A., Bennington, V., and Dutkiewicz, S.: Trends in the North Atlantic carbon sink: 1992-2006, Global Biogeochem. Cy., 23, GB4011, https://doi.org/10.1029/2008GB003383, 2009.

Verdy, A., Dutkiewicz, S., Follows, M. J., Marshall, J., and Czaja, A.: Carbon dioxide and oxygen fluxes in the Southern Ocean: Mechanisms of interannual variability, Global Biogeochem. Cy., 21, GB2020, https://doi.org/10.1029/2006GB002916, 2007.

Wang, S. and Moore, J. K.: Variability of primary production and air-sea $\mathrm{CO}_{2}$ flux in the Southern Ocean, Global Biogeochem. Cy., 26, GB1008, https://doi.org/10.1029/2010GB003981, 2012.

Wanninkhof, R., Park, G.-H., Takahashi, T., Sweeney, C., Feely, R., Nojiri, Y., Gruber, N., Doney, S. C., McKinley, G. A., Lenton, A., Le Quéré, C., Heinze, C., Schwinger, J., Graven, H., and Khatiwala, S.: Global ocean carbon uptake: magnitude, variability and trends, Biogeosciences, 10, 1983-2000, https://doi.org/10.5194/bg-10-1983-2013, 2013.
Wetzel, P., Winguth, A., and Maier-Reimer, E.: Sea-to-air $\mathrm{CO}_{2}$ flux from 1948 to 2003: A model study, Global Biogeochem. Cy., 19, GB2005, https://doi.org/10.1029/2004GB002339, 2005.

Yeager, S. G. and Robson, J. I.: Recent Progress in Understanding and Predicting Atlantic Decadal Climate Variability, Curr. Clim. Change Rep., 3, 112-127, https://doi.org/10.1007/s40641-0170064-z, 2017.

Yeager, S. G., Karspeck, A., Danabasoglu, G., Tribbia, J., and Teng, H.: A Decadal Prediction Case Study: Late Twentieth-Century North Atlantic Ocean Heat Content, J. Climate, 25, 5173-5189, https://doi.org/10.1175/JCLI-D-11-00595.1, 2012.

Yeager, S. G., Karspeck, A. R., and Danabasoglu, G.: Predicted slowdown in the rate of Atlantic sea ice loss, Geophys. Res. Lett., 42, 10704-10713, https://doi.org/10.1002/2015GL065364, 2015.

Yeager, S. G., Danabasoglu, G., Rosenbloom, N. A., Strand, W., Bates, S. C., Meehl, G. A., Karspeck, A. R., Lindsay, K. Long, M. C., Teng, H., and Lovenduski, N. S.: Predicting NearTerm Changes in the Earth System: A Large Ensemble of Initialized Decadal Prediction Simulations Using the Community Earth System Model, B. Am. Meteorol. Soc., 99, 1867-1886, https://doi.org/10.1175/BAMS-D-17-0098.1, 2018. 